\title{
OUERLIKE GESAG EN DIE GEMOLESTEERDE KIND - DIE TOEREIKENDHEID VAN DIE WET OP KINDERSORG 74 VAN 1983
}

\author{
J.A. Robinson \\ Departement Privaatreg \\ Potchefstroomse Universiteit vir CHO \\ POTCHEFSTROOM
}

\begin{abstract}
An analysis of the Child Care Act 74 of 1983 clearly illustrates that the Act is not directed at serving the best interest of the sexually abused child. Instead, it would seem that the prionity placed on the interest of the community (by emphasizing the role of the criminal procedure) or the finess of the parents to have custody of the child in child-care proceedings, is extremely detrimental to the interest of the child.

The suggestion is put forward that it has become ungent for a family count to be established. I matters of this kind such a court can do valuable work to serve the best interest of the child by focussing on his personal situation, his having been the victim of the abuse.
\end{abstract}

\section{INLEIDING}

By ' $n$ besinning oor die aard van die beskerming wat kinders teen die misbruik van ouerlike gesag en andersins (ook van regsweë) behoort te geniet, word daar dikwels gevind dat verhewe morele beginsels en aansprake gestel word. Aanhalings soos die volgende:

Mankind owes the child the best it has to give.

en

Your children are not your children. They are the sons and daughters of Life's longing for itself.!

vind byvoorbeeld neerslag in bepalings van die Deklarasie van die regte van die kind wat deur die Algemene Vergadering van die Verenigde Volke Organisasie op 20

\footnotetext{
${ }^{1}$ Aanhalings deur Pappas in voorwoord tot Law and the status of the child (1983 xovii.)
} 
November 1959 geproklameer is.

Die werklikheid van kindermishandeling en -molestering in die huidige tyd leer egter dat van hierdie verhewe ideale en beginsels nie veel kom nie. Die stelling dat oor die werklike omvang van kindermishandeling net gespekuleer kan word, ${ }^{2}$ is ongelukkig ook in pas met die ervaring van baie regpraktisyns en sosiale werkers. Die bedroewende prentjie kry nog verdere reliëf in die lig van statistiek (ten aansien waarvan daar gewaarsku word dat dit maar die sigbare gedeelte van die ysberg is) dat daar in 1986 landwyd 549 gevalle van fisiese mishandeling en 276 gevalle van seksuele mishandeling per maand deur kindersorgverenigings hanteer is. Ofskoon die statistiek nie onderskei tussen gevalle waar die ouers vir die mishandeling/molestering verantwoordelik is en andersins nie, illustreer dit ten minste dat kinders dringend effektiewe (regs). beskerming nodig het.

Teen hierdie agtergrond is dit gepas om die beskerming wat die kind van regsweë geniet van nader te oorweeg. ${ }^{3}$ Dit behoort te geskied binne die raamwerk van fundamentele begrippe wat in hierdie verband tipies aan die orde is, naamlik ouerlike gesag, die gesin, ouerlike tugbevoegdheid en kinderbeskerming. Ter aanvang word daarop gewys dat vir die doeleindes hiervan daar geen onderskeid getrek sal word tussen die seksuele molestering en die fisiese mishandeling van die kind nie 4 . Die klem word eerder op die aard van die uitoefening van ouerlike gesag geplaas.

\footnotetext{
2 Vgl. Herman \& Theart (1982:2). Volgens ander bronne soos byvoorbeeld in Anon (1988:2) is daar in 1987683 nuwe sake aangemeld ten opsigte van seksucel gemolestecrde kinders, asook 927 nuwe sake ten opsigte van fisies mishandelde en 5433 nuwe sake rakende verwaarloosde kinders. In die November/Desember-uitgawe van Kindersorg (1989:11) word vermcld dat wanneer die oorecnstemmende tydperk 1987 en 1988 vergelyk word, daar gedurende 1988 'n verbysterende toename van $67 \%$ in die seksuele molestering van kinders aangetoon kan word.

3 Dit is inderdaad ironies om van die misbruik van ouerlike gesag te prat wat die mishandeling/molestering van die kind tot gevolg het. Olmesdahl (1978:253) lig die posisie soos volg toe:

... child abuse is inherent in the discretion that legal rules confer on parents. What can be seen as sick and deviant is not necessarily qualitatively different from what many cultures have accepted as normal. Child abusc is one end of a continum starting with the legitimate exercise of parental authority. There is no clear cut point where the quantity and quality of physical force used becomes legally impermissible.

4 Van Oosten (1986:91) toon aan dat die begrip mishandeling wat 'n skepping van die Wet op Kindersorg is, geensins gedefinieer word nie. Dit lei tot onsckerheid of daar 'n onderskeid getrek kan word tussen die statutêre vorm van mishandeling en die gemeenregtelike verskyningsvorms van aanranding waaronder dan verkragting, onsedelike aanranding ensovoorts. Vir dic doeleindes van hierdic artikel word dié aspek daargelaat.
} 


\section{2. 'N TEORETIESE ANALISE VAN DIE STRUKTUUR VAN DIE GESIN EN DIE JURIDIESE RELEVANSIE DAARVAN}

Alvorens na die bepalings van die Wet op Kindersorg 74 van 1983 as primêre bron van beskerming van die kind teen die misbruik van die ouerlike gesag gekyk word, is dit belangrik dat eers teoreties-analities oor die strukturele aard van die gesin besin sal word. Dit kan kwalik anders aangesien die funksionaliteit van die statutêre beskermingsmeganismes telkens aan hierdie teoretiese onderbou getoets moet word ten einde vas te stel in welke mate die betrokke meganisme daarin slaag om aan die kind beskerming te bied. Optimale beskerming skyn slegs moontlik te wees indien die eiesoortigheid van die gesinstruktuur na behore verdiskonteer word. Uiteraard word die uitoefening van ouerlike gesag ook deur die teoretiese ontleding omlyn.

Ouerlike gesag as tipiese verskynsel binne gesinsverband ontbeer eiesoortige juridiese begrip. Daar bestaan 'n bepaalde teoretiese noodwendigheid vir dié toedrag wat terug te herlei is na die toeligting van wysgere soos Groen van Prinsterer, Kuijper en Dooyeweerd. Dooyeweerd (1933) toon aan dat die gesin as 'n natuurlike gemeenskap 'n eiesoortige sosiale entiteit met 'n struktuurtipiese eiesoortigheid is. Sosiale entiteite (waaronder die staat, kerk ensovoorts) word elk getipeer deur sy eie wesenskenmerke wat deur sy uniek-eie individuele funksies gemanifesteer word. Die funksies hier ter sprake is onderskeidelik die funderings- en bestemmingsfunksie van die betrokke sosiale entiteit.

Die funderingsfunksie van 'n sosiale entiteit is dié funksie,

waarin het kerntype der individualiteit van de betrokken samenlevingsverhouding besloten is (Dooyeweerd, 1962:102)

Hierteenoor dui die bestemmingsfunksie van die sosiale entiteit rigtinggewend die bestemming daarvan aan.

Deze interne bestemmingsfunctie heeft een typische richtinggevende en leidende rol binnen de individualiteitsstructuur. Zij ontsluit alle vroegere aspectfuncties van het geheel en richt ze op de typische innerlijke bestemming van dit laatste (Dooycweerd, 1962:100).

Die individualiteitstruktuur van die sosiale entiteit word bepaal deur die besondere samehang tussen die funderings- en die bestemmingsfunksie van die entiteit. 
Dooyeweerd (1931:209 e.v.) toon aan dat die gesin as sosiale entiteit biologies gefundeer is en ter ondersteuning van sy argument wys hy daarop dat die gesin 'n eiesoortige struktuurfondament het wat daaruit spruit dat kinders die natuurlike afstamming van ouers is en deur bande van bloedgemeenschap aan die ouers verbind is.

Soos hierbo aangetoon, word die fundering van die sosiale entiteit deur die rigtinggewende moment daarvan gekwalifiseer. Die bestemming van die gesin is in die etiese geleë.

St :eds wordt ons het gezin naar zijn goddelijke struktuur voorgehouden als een typische normatieve liefdesgemecnschap op den grondslag van de natuurlijke banden des bloeds tusschen ouders en kinderen ...

En als structurcle functic van het gezin is hij (de liefdesband) inderdaad de qualificeerende, morcele bestemmingsfunctie, welke, naar de normatieve levenswet van dit verband, alle vroegere structuurfuncties de interne richting en leiding behoort te geven (Dooyeweerd, 1931:214).

Liefde as inhoudelike moment van die eties-morele het tot gevolg dat ouerlike gesag vir die doeleindes van juridiese aktiwiteit nie eiesoortig juridies verklaar kan word nie Dit hang daarmee saam dat die etiese in 'n geantisipeerde posisie ten aansien van dié van die juridiese staan. (Vgl. Van Zyl \& Van der Vyver, 1987:27 e.v.; Strauss, 1978:43; Dooyeweerd, 1931:94 e.v.). Elders lig Dooyeweerd (1933:405) die uiteensetting toe met die verduideliking dat slegs die wetskringe van die moreel-etiese en die geloof na dié van die juridiese in die rangorde van die kosmiese orde volg. Ofskoon Dooyeweerd dit hier primêr het oor die objektiveerbaarheid van entiteite as regsobjekte, tref sy verduideliking myns insiens meteen ook die vraag nou onder bespreking, naamlik of ouerlike gesag volledig juridies verklaar kan word. Omdat in beginsel slegs dit wat ekonomiese waarde het in die sin daarvan dat dit relatief skaars is regtens geobjektiveer kan word, kan 'n morele liefdesverhouding of 'n geloofsoortuiging nie regtens geobjektiveer word nie. Toegepas op die uitoefening van die ouerlike gesag hou dit in dat die liefdeskwalifikasie ten aansien van die gesagsmoment 'n eiesoortige kwalifikasie bied wat tot gevolg het dat ouerlike gesag as begrip nie volledig juridies verdiskonteer kan word nie. Namate daar egter met sodanige etiese beginsels en norme rekening gehou word, kan daar gesê word dat die betrokke regsnorme meer ideaal word.

Die toepassing van die (enigsins oorsigtelike) teoretiese uiteensetting rondom die struktuur van die gesin het besondere implikasies vir sowel die wyse van uitoefening van ouerlike gesag as vir die aard van (regs-)middele en instellings wat ten doel het om die kind teen die misbruik van ouerlike gesag te beskerm. As vertrekpunt word geneem dat daar by sowel die uitoefening van ouerlike gesag as by die regsproses ter beskerming van 
dat daar by sowel die uitoefening van ouerlike gesag as by die regsproses ter beskerming van die kind teen die misbruik daarvan met die eiesoortige struktuur van die gesin rekening gehou behoort te word ${ }^{5}$ en dit kan selfs verg dat gespesialiseerde strukture ter bereiking van die doel geskep behoort te word. Die eiesoortige aard van die gesinstruktuur maak dit 'n sine qua non dat die regsproses wat gerig is op die remediëring en vergelding van die misbruik van die ouerlike gesag jeens die kind, van sodanige aard moet wees dat dit primêr op die eiesoortige aard van die gesin afgestem moet wees. Sodanige regsproses, en nie die straf- en strafprosesreg nie, behoort die "eerste linie van remedie" vir die beskerming van kinders teen die misbruik van ouerlike gesag jeens hulle te wees.

\section{OUERLIKE GESAG TEN AANSIEN VAN DIE PERSOON VAN DIE KIND}

Soos hierbo aangetoon, is ' $n$ juridies afdoende omskrywing van ouerlike gesag kwalik denkbaar. Die aard en die wyse van uitoefening daarvan is egter reeds meermale deur ons howe in oorweging geneem. Aan die oppervlak skyn die uitleg wat aan die begrip geheg word in pas te wees met omskrywings van die regsaard daarvan soos dit internasionaal aangetref word. Ter wille van volledigheid word kortliks op die historiese ontwikkeling rondom ouerlike gesag gewys. In sowel die Suid-Afrikaanse as die Nederlandse reg word die regsfiguur van ouerlike gesag na die patria potestas-figuur van die Romeinse reg herlei. Asser (1984: 134) toon aan dat die patria potestas ingehou het dat die kind as die eiendom van die pater familias beskou is. In die vroeë Romeinse reg het die potestas die mag van lewe en dood (ius vitae necisque) ingesluit en dit het ook die mag behels om diegene wat daaronder geval het as slawe te verkoop. Latere ontwikkeling het egter temperend daarop ingewerk sodat die paterfamilias nie sy kinders straffeloos kon dood of verkoop nie. Hy kon hulle slegs tugtig. Die patria potestas het met bepaalde verpligtinge gepaard gegaan, waaronder die verpligting om sy kinders te onderhou. (Vgl. byvoorbeeld Van der Vyver \& Joubert, 1985:596; Asser, 1984:134; Van Warmeloo, 1971:52.) Vgl. ook Olmesdahl (1978:253 e.v.).

Die Germaanse reg het bepaalde ooreenkomste met die Romeinse reg getoon, alhoewel die moeder ook in 'n mate gesag ten aansien van die kinders gehad het. Die ouerlike gesag het egter nog uitsluitlik by die vader berus.

In die Romeins-Hollandse reg het die posisie egter sodanig daar uitgesien dat sowel die vader as die moeder gesag oor die persoon van die kind gevoer het. Daar was dus

\footnotetext{
${ }^{5}$ Dit spreck vanself dat dic instelling van ' $n$ gesinshof ' $n$ moontlikhcid is wat aan hierdie premis gestalte kan gee. Vgl. slotparagraaf.
} 
'n verskuiwing van die patria potestas na ouerlike gesag wat deur sowel die vader as die moeder gevoer is. (Vgl. Meyer v Van Niekerk 19761 SA 252 (T) op 252 en 256). Die gevolg hiervan was byvoorbeeld dat, anders as in die Romeinse reg, die ouerlike gesag oor die kind by die moeder berus het in die geval van die afsterwe van die vader, in plaas van by 'n tutor. Die ouers was egter verplig om hulle kinders te onderhou en uit hoofde van die ouerlike gesag moes hulle ook hulle kinders opvoed, versorg en beskerm. Die kinders was gehoorsaamheid aan hulle ouers verskuldig en die ouers was geregtig om hulle kinders te tugtig.

Breedweg word daar aanvaar dat ouerlike gesag die gesag van die ouer oor die kind behels uit hoofde waarvan die ouer kompetent is om sekere besluite ten aansien van die kind te neem en in die uitvoering daarvan gehoorsaamheid van die kind te eis (Vgl. onder andere Luijten (1970:228 e.v. ten aansien van die regsposisie in Nederland; Mnookin Child, (1978: 39, 113 e.v.) en ook Ryan \& Granfield (1963:479 e.v.) ten aansien van die regsposisie in die VSA. Ten opsigte van die regsposisie in Brittanje, vergelyk Clark, et al (1972:886) en Freeman (1983:601 e.v.)).

Die regsposisie rondom die aard en uitoefening van ouerlike gesag in Israel kan as voorbeeld genoem word waar die verhouding tussen ouers en kinders statutêre beslag gekry het. In artikel 14 van die Capacity and Guardianship Law van 1962 word bepaal dat ouers die natuurlike voogde van hulle minderjarige kinders is. Artikel 15 lui dat

(t)he duty and the right to take care of the needs of the minor, including his education, studies, vocational and occupational training and work, and to preserve, manage and develop his property ...

deur ouerlike gesag ingesluit word. Die reg van toesig oor die minderjarige, die keuse van 'n woonplek en die kompetensie om namens die minderjarige regshandelinge aan te gaan, word ook daarby ingesluit.

In die Suid-Afrikaanse positiewe reg kristalliseer die aard van ouerlike gesag soortgelyk uit en manifesteer dit eweneens in gepaardgaande verpligtinge om huisvesting, voedsel, kleding, geneeskundige hulp asook 'n gepaste opvoeding aan die kind te verskaf. Die kriterium wat telkens aangewend word om te bepaal of die ouers hulle in afdoende mate van hulle verpligting gekwyt het, is die redelikheidsmaatstaf. Joubert (in Van der Vyver \& Joubert, 1958:58; 609 e.v.) praat in hierdie verband daarvan dat die nakoming van die ouerlike verpligtinge aan die norme van die gemeenskap moet voldoen ${ }^{6}$.

6 aw 611. 
In Hawthorne $v$ Hawthorne ${ }^{7}$ word die redelikheidsbegrip spesifiek met die feite van die saak in verband gebring en soos volg toegepas:

The Applicant was compelled to take some step in protection of the children; she acted in a reasonable manner.

(t)hat in this case it was reasonable to provide the boys with football boots. (My kursivering.)

Die redelikheidsbegrip speel ook 'n deurslaggewende rol ten aansien van die tugbevoegdheid van ouers. Dit is vanselfsprekend dat ouers ter nakoming van hulle verpligtinge die kind moet kan verplig om hulle te gehoorsaam (Spiro, 1985:89; Van der Vyver \& Joubert, 1985:612). Daarom mag ouers hulle kinders deur middel van 'n gepaste en redelike straf tugtig. In gepaste gevalle mag lyfstraf redelik wees en ter bepaling van die vraag of dit wel redelik was, word gelet op bepaalde faktore, waaronder die aard en erns van die oortreding, die liggaamlike en geestelike toestand van die kind, die aard van die tugmiddel en die metode, die mate van straf wat toegedien is en die doel en motief van die persoon wat die straf toedien. (Vergelyk Spiro, 1985: 89. Vir 'n volledige bespreking van hierdie aangeleentheid, kyk Heaton, 1987:398 e.v.).

Die howe meng nie geredelik in met die ouerlike diskresie ten aansien van die uitoefening van tug nie ${ }^{8}$, the presumption being that punishments by parents are not dictated by improper motives" (Spiro, 1985:89). Is die straftoediening in die lig van die bogemelde omstandighede redelik, tree die ouer regmatig op. Indien dit nie redelik is nie, is sy optrede onregmatig en kan hy van 'n misdryf aangekla word'.

Uit Joubert en Spiro se opmerkings soos hierbo aangedui dat 'n ouer regmatig handel as hy binne die perke en redelikheid sy kind tugtig, blyk dit dat ouerlike gesag en die redelike uitoefening daarvan 'n regverdigingsgrond is wat die onregmatigheid van 'n aanrandingshandeling op die kind uitsluit. 'n Ouer tree met ander woorde binne die perke van sy reg op as sy tugtigende optrede jeens die kind redelik is.

\footnotetext{
719503 SA 299 (C).

${ }^{8} R$ v Janke \& Janke 1913 TPA 382 op $385-6$.

"In die Nederlandse reg bepaal art 245(1) van die Burgerlijk Wetboek dat kinders ongeag hulle ouderdom eerbied en ontsag aan hulle ouers verskuldig is. Hierdie bepaling word teruggevoer na De Groot se uiteensetting dat dit Goddelike reg is dat kinders hulle ouers moet gehoorsaam. In die Burgerlijk Wetboek word daar klaarblyklik nie voorsiening gemaak vir tuguitocfening deur oucrs nie. In dic Engelse reg sien die posisie soortgelyk as dié in Suid-Afrika daaruit. Vgl. Frceman (1983:626).
} 
In die lig daarvan dat daar betreklike eenstemmigheid oor die aard van ouerlike gesag heers, behoort vervolgens oorweeg te word op welke wyse ouerlike gesag genuanseer behoort te word - is dit 'n kompetensie wat na willekeur en met 'n minimum van ingrype van regsweë uitgeoefen mag word of behoort dit juis in die belang van die kind uitgeoefen te word? Die motivering vir hierdie werkmetode hang daarmee saam dat die beklemtoning van of die ouerlike gesagsaspek df die belang van die kind tot verskillende nuanseringe aanleiding gee, terwyl sulke nuanseringe tot dramaties verskillende praktyksbenaderinge lei wanneer die beskerming van die kind teen die misbruik van ouerlike gesag onder die loep kom.

Dit loon die moeite om in hierdie verband teoreties-regsvergelykend na die voorskrifte van 'n moderne gekodifiseerde regstelsel soos die Nederlandse reg te kyk. Dit is algemeen bekend dat die beskerming van die kind in die betrokke regstelsel besonder omvangryk gereël word. Artikels 245 en 246 van die Burgerlijk Wetboek handel oor ouerlike gesag. Artikel 245(2) lui dat ouers die verpligting het om hulle kinders te versorg en op te voed. Die mate waarin hulle daartoe verplig is, word deur hulle vermoë (draagkracht) bepaal. Hoe die versorging en opvoeding daar moet uitsien, word nie statutêr nader omlyn nie en die ouers kan volgens hulle diskresie daaraan voldoen (onderhewig natuurlik aan bepaalde sanksies indien hulle tekort sou skiet aan algemeen aanvaarde norme soos op hulle spesifieke omstandighede van toepassing) (Vergelyk onder andere Kakebeeke van der Put. 1978:106).

In die Engelse reg het die beskerming van kinders teen die misbruik van ouerlike gesag voor die aanvang van hierdie eeu eweneens bedroef daaruit gesien. So word daar byvoorbeeld geskryf dat kinders aan die begin van die Industriële Revolusie beskou is as

(1)egally the property of their parents. They were used by them as personal or family assets... Among the poor, the labour of children was exploited; among the rich, their marriages were contrived; all to the cconomic or social advantage of the parents (Pinchbeck \& Hewitt, II, 1973:348).

Die posisie het egter veral sedert die begin van die eeu sodanig ontwikkel dat ouers benewens bepaalde regte wat hulle ten aansien van hulle kinders gehad het, ook die verpligting opgelê is om hulle te beskerm deur hulle fisies te versorg en van 'n "proper upbringing" te voorsien. Hulle moet ook toesien dat hulle kinders effektiewe opleiding ontvang wat vir die kind se vermoëns en omstandighede van pas is. (Vgl. Freeman, 1983:625 e.v.) Ouers het ook bepaalde regte ten aansien van hulle kinders waaronder die reg van beheer en toesig, die reg om die kind se opleiding te bepaal en die reg om die kind se godsdienstige opvoeding te bepaal. In die VSA sien die posisie soortgelyk aan dié van Suid-Afrika daaruit (vgl. Soler et al., 1983:692 e.v.). 
Die Nederlandse reg pas na 1901 het in wese twee gedagtestrominge vergestalt. Enersyds is aanvaar dat dit die reg van die ouers is om die opvoeding van hulle kinders as hulle eie verantwoordelikheid te beskou. Dit sou inhou dat hulle alleen en sonder inmenging die lotsbestemming en opvoeding van hulle kinders kon bepaal. Andersyds is daar van die standpunt uitgegaan dat ouerlike gesag alleen tot voordeel van die kind uitgeoefen moet word en dat dit die regsorde daarom vrystaan om te bevestig dat die ouerlike gesag werklik in die belang van die kind uitgeoefen is. Daarom moes ook voorsiening gemaak word vir ingrype deur die regsorde indien dit nie die geval sou wees nie. 'n Burgerlike kindenwet van 6 Februarie 1901 wat in 1905 in werking getree het, het egter bepaalde voorkeur aan die tweede uitgangspunt verleen, sodat die ouer nie slegs regte ten aansien van die kind het nie, maar ook verpligtinge. (Vgl. verder hieroor onder andere Asser, 1984:138; Luijten, 1970:226).

Die bedoeling is nie om die Nederlandse regsposisie te ontleed ten einde die argument te staaf dat ouerlike gesag ter wille van die kind uitgeoefen moet word nie. Dit is voldoende om daarop te wys dat daar heelparty remedies tot beskikking van die kind is in die geval waar die ouerlike gesag jeens hom misbruik word en dat die belang van die kind in elk geval van deurslaggewende belang is. Artikel 254 van die Burgerlijk Wetboek wat vir gesinsvoogdy voorsiening maak, lui dat indien 'n kind op sodanige wyse opgroei dat dit sy zedelijke of lichamelijke ondergang tot gevolg het, 'n gesinsvoog aangestel kan word om die ouer/voog by te staan in die opvoeding van die kind. Voorts kan 'n ouer uit hoofde van artikel 266 van sy ouerlike gesag onthef word as hy ongeschikt of onmachtig is om sy plig tot versorging en opvoeding van die kind te vervul, mits dit in die belang van die kind is. In gevalle waar die ouer hom jeens die kind wangedra, moet hy van die ouerlike gesag ontset word. Dit handel hier oor gevalle soos die misbruik van ouerlike gesag, growwe verwaarlosing van die kind of slecht levensgedrag. Die wangedrag op sigself genome bied nie rede vir die ontsetting nie - artikel 269 maak dit duidelik dat ook in hierdie gevalle dit in die beste belang van die kind moet wees dat die bevel uitgereik word. Die uitgangspunt is dat dit in die beste belang van die kind is om binne sy natuurlike familieverband op te groei. Om hierdie rede word daar 'n hoë premie geplaas op die heropbouprogram van die familie na ingrype van regsweë sodat die kind weer in sy ouers se sorg geplaas kan word indien dit in die omstandighede moontlik is.

In die Suid-Afrikaanse reg kom dit voor dat daar van regsweë terughoudendheid bestaan om ten aansien van die uitoefening van ouerlike gesag in te gryp en dat die kind gevolglik in sommige gevalle onvoldoende beskerming teen die misbruik daarvan 
geniet. Toeligting vir hierdie stelling volg in paragraaf 4 hieronder. Voorlopig word egter gekonkludeer dat die verskil in benadering tot die aard van ouerlike gesag soos onderskeidelik in die regsposisies in Nederland en Suid-Afrika gemanifesteer, neerslag vind in die aard van die beskermingsmeganismes wat ter beskerming van die kind teen die misbruik van ouerlike gesag daargestel word.

'n Verdere (en enigsins voorlopige) gevolgtrekking wat reeds nou gemaak kan word, hang saam met die belangrikheid van die redelikheidsbegrip ten aansien van die uitoefening van ouerlike gesag. Die liefdesbestemde eiesoortigheid van ouerlike gesag lei daartoe dat die howe genoop word om van 'n juridies-eenduidige begrip wat as standaard gestel word, gebruik te maak waarteen afwykings wat binne die gesinsverband as onredelik getipeer kan word, geremedieer en vergeld kan word.

\section{DIE BEPALINGS VAN DIE WET OP KINDERSORG TEN AANSIEN VAN DIE BESKERMING VAN KINDERS}

In hierdie paragraaf word hoofsaaklik gekyk na die voorskrifte van die Wet op Kindersorg 74 van 1983 (hierna die Wet genoem) om 'n waardebepaling te maak in welke mate ouerlike gesag as 'n verskynsel wat ten gunste van die kind uitgeoefen moet word, behandel word. Daar sal gepoog word om aan te toon dat daar in die $W c t$ argaïese reste te vinde is van 'n uitgangspunt dat ouerlike gesag nie ongekwalifiseerd in die beste belang van die kind uitgeoefen hoef te word nie.

Die Wet is verdeel in 9 hoofstukke. Hoofstuk 3 behandel die beskerming van kinders terwyl hoofstuk 8 oor die voorkoming van mishandeling en onwettige verwydering van kinders handel. Die primêre verskil tussen hierdie twee hoofstukke lê daarin opgesluit dat in hoofstuk 8 voorsiening gemaak word vir die kriminele vervolging van ouers wat hulle kinders mishandel of verlalat of versuim om hulle na behore te onderhou ${ }^{10}$, terwyl hoofstuk $3 \mathrm{klem}$ lê op die bevoegdhede van die kinderhof ten aansien van ouers wat

\footnotetext{
${ }^{10}$ Art 50 lui soos volg:
}

(1) 'n Oucr of voog van 'n kind of iemand in wie se bewaring 'n kind is wat

(a) dic kind mishandel of toelaat dat hy mishandel word; of

(b) dic kind verlaat is aan 'n misdryf skuldig.

(2) Jemand wat wettiglik verantwoordelik is vir die onderhoud van 'n kind en wat versuim on die kind van genocgsame voedsel, kleding, herberg en mediese behandeling te voorsien, terwyl hy wel in staat is om dit te doen, is aan 'n misdryf skuldig. 
hulle aan bepaalde gedrag jeens die kind skuldig maak ${ }^{11}$. Teen hierdie agtergrond moet vasgestel word in welke verhouding die twee hoofstukke teenoor mekaar staan aangesien albei in wese op die beskerming van die kind teen die misbruik van ouerlike gesag gerig is. In hierdie verband moet gelet word op die verduideliking van die Minister van Gesondheid en Welsyn in die tweede lesingsdebat (8 Mei 1983) van die bespreking van die wetsontwerp (Hansard, 1983, kol. 8318).

Sterk klem word die afgelope twee dekades op voorkomingsdienste met betrekking to kindersorg gelê. Die uitgangspunt is vandag om die kinders en hulle ouers sover moontlik uit die kinderhof te hou. Ons leef nie meer in die dae waarin die enigste beskerming wat 'n kind gebied kan word, is om sy ouers te straf of om die kind in 'n inrigting op te neem nie. 'n Welsynorganisasie het my meegedeel dat in minder as $10 \%$ van die gevalle van beweerde sorgbehoewendheid die Kinderhof se hulp nodig is om substituutsorg vir kinders te reël. In minder as $1 \%$ van die gevalle het 'n maatskaplike werker die kinderhof se hulp nodig om die terapeutiese dienste ten opsigte van ouers ten uitvoer te bring.

Hoofstuk 3 van die wetsontwerp is dan ook net bedoel as 'n hulpmiddel vir maatskaplike werkers om te kan optrec in uiterste gevalle waar die kind onmiddellike beskerming nodig het of waar ouers en kinders se samewerking nie verkry kan word nie. Dit is om hierdie rede dat daa nou ook aan sekere maatskaplike werkers, byvoorbeeld die in diens van geregistreerde gesinsorganisasies, die reg verleen sal word om in uiterste gevalle kinders sonder vooraf toestemming of 'n lasbrief na 'n veiligheidsplek te verwyder.

Hierdie toeligting het myns insiens tot gevolg dat hoofstuk 8 eerder as die beskermingsmeganisme vir die gemolesteerde kind gesien word ${ }^{12}$. Dit is algemene kennis dat

\footnotetext{
${ }^{11}$ In art 14(4) van die Wet word gehandel oor die gevalle waar die kinderhof 'n ondersoek uit hoofde van artikel 13(3) instel. Subartikels (a) en (b) skryf die aard van die bevindinge voor waartoe die hof moet geraak, byvoorbeeld (a) dat die kind geen ouer of voog het nie, of (b) dat die kind 'n ouer of voog het wat nie in staat of geskik is om die bewaring van die kind te hê nie deurdat hy byvoorbeeld (i) dermate geestesongesteld is dat hy nie vir die maatskaplike, geestelike of verstandelike welsyn van die kind voorsiening kan maak nie, of (ii) deurdat hy die kind aangerand of mishandel het, of (iii) deurdat hy die verleiding, ontvoering of prostitusie van die kind of die pleging van onsedelike handelinge deur die kind veroorsaak het of in die hand gewerk het, of (iv) gewoontes en gedrag openbaar wat die liggaamlike, verstandelike of maatskaplike welsyn van die kind ernstig kan benadeel, of (v) versuim om die kind na behore te onderhou, of (vii) die kind verwaarloos of toelaat dat hy verwaarloos word of (ix) die kind verlaat het.

12'n Verdere aanduiding ter stawing van hierdie gevolgtrekking hang saam met die gebruik van die begrip mishandeling in art. 50. Die artikel skep inderdaad 'n statutêre misdryf, maar ironies genocg word daar in die woordomskrywing van die Wet geen omskrywing van die begrip gebied nie. Ecn gevolgtrekking wat sekerlik voortvloei uit die feit dat die Wetgewer met die breë omskrywing volstaan, is juis dat dit die bedoeling van die Wetgewer is om te voorkom dat die artikel eng geïnterpretecr sal word en om op dié wyse sy aanwendingsgebied te beperk. Oor die vraag of daar ' $n$ verskil is tussen die begrippe mishandeling en aanranding kan Van Oosten (1983:86 e.v.) geraadpleeg word.
} 
daar inderdaad ouers is wat hulle vrywillig aan terapeutiese dienste onderwerp wat daarop gerig is om die misbruik van die ouerlike gesag te voorkom. Dit is egter ook algemene kennis dat nie alle ouers bereid is tot onderwerping aan sodanige dienste nie. Dit skyn my nie vergesog nie om te redeneer dat die rede vir die minder as $1 \%$ van die gevalle waar die maatskaplike werker die kinderhof se hulp nodig het om die terapeutiese dienste ten opsigte van die ouers ten uitvoer te bring, juis daarin geleë is dat die strafproses reeds sy weg begin loop het en dat ouers uit vrees vir strafoplegging wat hangende is of wat opgeskort is, samewerking gee ${ }^{13}$. Die kwaliteit en duur van ouerlike gedrag wat om hierdie rede "verbeter" het, word bevraagteken.

Die feit dat prakties aan kriminele vervolging voorkeur verleen word, roep ernstige bedenkinge teen die wet na vore. Dit hang saam met aspekte rondom die bewyslas in kriminele sake ${ }^{14}$. Dit is geykte reg dat die bewyslas wat op die staat in geval van kriminele vervolging rus, bewys bo redelike twyfel is. Dit beteken dat die staat elke bestanddeel van die misdaad bo redelike twyfel moet bewys ${ }^{15}$. As 'n reël dra die beskuldigde geen bewyslas nie. Daar rus hoogstens 'n weerleggingslas op hom en dit hou in dat hy slegs twyfel hoef te skep ten aansien van sy skuld. In sommige gevalle sou hy dit kon doen selfs al sou hy swyg 16 .

Die resultaat wat deur die beklemtoning van die strafregtelike sanksies vir die mishandelde of gemolesteerde kind geskep word, is vanselfsprekend. Daar moet bewys word dat die ouers die kind mishandel of verwaarloos het of toegelaat het dat hy mishandel of verwaarloos word ${ }^{17}$. Die probleem wat hierdeur teweeggebring word is dat baie kinders vanweë jeugdigheid eerstens nie in staat is om die regsproses in werking te stel om die ouers te laat vervolg nie. Tweedens bring dit mee dat selfs in gevalle waar die saak wel voor 'n kriminele hof dien, die streng bewyslas en die dikwels jeugdige ouderdom van die slagoffer tot gevolg het dat hy sy ervaring nie voldoende kan beskryf en daaroor getuig nie. Dit lei dikwels daartoe dat 'n ouer (ten onregte?) onskuldig bevind word. Dit is nodeloos om te sê dat dit die kind se posisie nog verder

\footnotetext{
${ }^{13} \mathrm{Vgl.} \mathrm{meegaande}$ teks tot voetnoot 18 hieronder.

${ }^{14}$ Dic verdere praktiesc vraag, naamlik of dic maatskaplike werker eerder hoofstuk 3 as hoofstuk 8 in werking sal stel, word daargelaat.

${ }^{15} \mathrm{Vgl}$. Ex pare Minister of Justice: In re $R$ v Bolon 1941 AD 345.

${ }^{16} \mathrm{Vgl} . S$ v Fouche 19741 SA 96 (A) en S v Maritz 19741 SA 266 (NK).

${ }^{17} \mathrm{Vgl}$. art. $50(1)$ (a) Wet 74 van 1983.
} 
verswak.

Daar is ook bepaalde newegevolge daaraan verbonde dat die strafregtelike beskerming voorop staan. Die belange van die kind kan ernstig hierdeur in gevaar gestel word deurdat die herstel van 'n normale gesinsverhouding ernstig benadeel kan word. Die praktiese situasie kan byvoorbeeld so daaruit sien dat die hof, na aanhoor van die maatskaplike werker se verslag, van oordeel is dat 'n besondere swaar vonnis opgelê moet word. Dit word bevraagteken of so 'n ouer enige vertroue in die maatskaplike werker sal hê en dat hy juis as gevolg van hierdie antipatie geen samewerking sal gee met die heropbouprogram van die gesin nie. Die kanse word deur hierdie benadering dus aansienlik verskraal dat die kind by die ouers teruggeplaas sal word of dat ' $n$ gesonde ouer-kindverhouding herstel sal word ${ }^{18}$.

Vanuit regsteoretiese perspektief is dit onaanvaarbaar dat die eiesoortige struktuur van die gesin deur die beklemtoning van die strafregtelike remedies deur die voorskrifte van die Wet ontken word. In plaas daarvan dat 'n regsproses wat gerig is op die eiesoortigheid van die gesin aangewend word ter vergelding (en remediëring) van die misbruik van ouerlike gesag, word die straf- en strafprosesreg nou as "eerste linieremedie" gesien. Dit vereis kwalik enige betoog dat die kriminele howe geensins as die primêre forum gesien kan word vir die beskerming van die kind teen die misbruik van die ouerlike gesag nie. Ofskoon dit so is dat daar meerdere strafteorieë bestaan, met ander woorde teorieë ter verduideliking waarom 'n persoon vir bepaalde gedrag gestraf moet word, het al die teorieë in mindere of meerdere mate die beskerming van die gemeenskap as eerste prioriteit. So blyk dit uit die vergeldingsteorie dat die teorie primêr op die feit berus dat die misdaad die juridiese balans in die samelewing versteur het en dat hierdie wanbalans nou herstel moet word deur die misdadiger vir sy wandaad te straf. Deur sy wandaad negeer of verloën die oortreder die reg en wanneer hy nou regtens gestraf word, kom daar weer ' $n$ "ewewigtigheid in die skale van geregtigheid" en kan 'n mens sê dat hy deur sy straf sy verdiende loon gekry het (vgl. Snyman,1983:14 e.v.). Dit is geensins die bedoeling om aan die rol van die strafreg in gevalle van hierdie aard minderwaardige status te gee nie. Veel eerder word betoog dat die beskerming van die gemolesteerde kind in gevalle van hierdie aard voorop moet staan en dat die beskerming van die kind in toepaslike gevalle selfs daartoe kan lei dat dit ontoepaslik kan wees om die kriminele proses teen die dader-ouer in werking te stel.

\footnotetext{
${ }^{18} \mathrm{Vir}$ die docleindes van die argument is na die strafregtelike optrede teen die ouers verwys. Soos hieronder uiteengesit is art. 14(4) wat vir die instel van 'n ondersoek deur die kinderhof voorsiening maak, in wese ook daarop gerig om die gedrag van die ouer te ondersoek. Hierdie argument geld dus mutatis mutandis ook vir ondersoeke deur 'n kinderhof uitgevoer.
} 
Ingevolge die vergeldingsteorie is straf ' $n$ doel op sigself. Die houdbaarheid van die ongekwalifiseerde toepassing van so 'n absolute teorie word egter onder verdenking gebring in die gevalle waar die beskerming van die kind verg dat die kriminele proses nie in werking gestel word nie. Die belang en veiligheid van die kind kan juis verg dat die ouer-dader vrygestel moet word van die smet van kriminele vervolging, onderhewig daaraan dat voldoende meganismes ter beskerming van die kind se welsyn geskep word.

In die geval van 'n kinderhofondersoek ingevolge die voorskrifte van hoofstuk 3 van die Wet bestaan daar eweneens wesenlike probleme. (Vir die doeleindes van hierdie artikel word met 'n bespreking van artikels 14 en 15 van hoofstuk 3 van die Wet volstaan.) Artikel 15(1) bepaal dat 'n kinderhof wat na ondersoek oortuig is dat 'n betrokke kind nie ouers of 'n voog het wat in staat is of geskik is om bewaring van die kind te hê nie, bepaalde bevele rondom die kind se bewaring kan maak. Kennelik is die woorde "oortuig is" daarop gerig dat die voorsittende beampte geen twyfel moet hê ten aansien van die faktore soos in artikel 14(4)(a) en (b) uiteengesit nie. Opsommenderwys kan gesê word dat die hof oortuig moet wees dat dit juis die ouer se onvermoë en ongeskiktheid is wat verantwoordelik is vir die toestand waarin die kind hom bevind. Teen hierdie agtergrond is ' $n$ bepaling soos dié in artikel 14(2) dat die kommissaris 'n maatskaplike werker kan versoek om 'n verslag oor enige aangeleentheid te verstrek, verstommend. In die lig van die hoë mate van sekerheid wat by die kommissaris moet bestaan alvorens hy so 'n bevel maak soos in artikel 15(4) uiteengesit, sou 'n imperatief in hierdie omstandighede eerder toepaslik wees. Gegewe dat die ouerlike ongeskiktheid of onvermoë blyk uit optrede teenoor'n kind (wat soos hierbo uiteengesit, dikwels nie in staat is om sy ervaring dermate te beskryf dat die staat kan steun op sy getuienis om sy saak bo redelike twyfel te kan bewys nie) en dat hierdie negatiewe ouerlike optrede in die privaatheid van 'n huis of woning plaasvind, is die voorskrif dat 'n kommissaris 'n verslag kan aanvra, gewoon ontoereikend.

Dit is ook vanselfsprekend dat die strekking van artikel 15(1) soortgelyk is aan dié in 'n strafregtelike ondersoek, naamlik dat dit die ouer se vermoë is wat onder die loep geneem word, eerder as die sorgbehoewendheid van die kind. Dit is daarom duidelik dat die newegevolge van so 'n benadering soortgelyk is aan dié van kriminele vervolging soos hierbo uiteengesit.

'n Laaste argument ter illustrasie van die gebrekkige beskerming wat deur die Wet aan die kind gebied word, hang enersyds saam met die kousale verband tussen die ouerlike optrede en andersyds die mishandeling, seksuele misbruik of verwaarlosing of enige 
van die omstandighede vermeld in artikel 14(4). Omdat dit primêr gaan oor die ouerlike onvermoë of ongeskiktheid om sy ouerlike gesag na behore uit te oefen, is dit duidelik dat in die geval van strafregtelike verrigtinge, sodanige onvermoë of ongeskiktheid bo redelike twyfel bewys moet word, en in die geval van 'n kinderhofondersoek, dat die kommissaris daarvan oortuig moet wees. Indien die hof dus nie dermate oortuig is dat dit die ouers is wat vir hierdie omstandighede verantwoordelik is nie, selfs al word bewys dat die kind seksueel gemolesteer, verwaarloos of mishandel is, word die kind feitlik onbeskermd gelaat teen verdere misbruik van die ouerlike gesag soos in artikels 14(4) en 50(1) onderskeidelik uiteengesit.

Dit is sekerlik nie onvanpas om ten aansien van die beskerming wat die Wet op Kindersorg aan die gemolesteerde kind bied, te konkludeer nie dat dit wesenlik ontoereikend is. Die klemverskuiwing van sorgbehoewende kind (soos dit in die Kinderwet van 1960 voorgekom het) na die geskiktheid en vermoë van die ouer het bedroef min gedoen om die kind te beskerm.

\section{SLOT}

Die praktyk rondom die toepassing van van die bepalings van die Wet leer dat die regsverteenwoordiger van die molesteerder-ouer (wat uiteraard die beskerming van sy kliënt se belange voorop stel) en betrokkenes vanuit die hulpprofessies wat na die kind se belange omsien, dermate in 'n regsproses betrokke raak om die ouers se geskiktheid of bevoegdheid te bepaal, dat die belang van die kind 'n betreklik ondergeskikte posisie in die proses inneem. Die situasie is ' $n$ logiese gevolg van die vertrekpunt van die Wet dat die ouerlike geskiktheid of bevoegdheid voorop staan. Vanuit die breë spektrum van wetenskaplike arbeid en spanwerk deur vakwetenskaplikes wat met die probleem gemoeid is en op die beste belang van die kind gerig is, kom daar vanweë klemverskuiwing nie veel tereg nie. Dit skyn trouens dat daar eerder wantroue en onsekerheid by die persone jeens die betrokkenheid van ander vakwetenskaplikes by die ondersoek bestaan.

Daar word gevolglik betoog dat dit haas tyd geword het dat die regsproses in hierdie verband eerder aanduidend daarvan behoort te wees dat dit enersyds die eiesoortigheid van die gesinstuktuur erken en andersyds dat dit toesien dat ouerlike gesag in die belang van die kind uitgeoefen word. Daar is reeds in die Verslag van die Hoexterkommissie aanbeveel dat 'n gesinshof met uitgebreide bevoegdhede (ook strafbevoegdheid) op die been gebring behoort te word om sake van familieregtelike aard te bereg. Die Kommissie het waardevolle werk gedoen en daar kan kwalik tot 'n ander gevolg. 
Ouerlike gesag en die gemolesteerde kind - die toereikendheid van die Wet op Kindersorg

trekking geraak word as dat dit tans dringend noodsaaklik geword het om opnuut oor die instelling van so 'n gesinshof te besin.

\section{BIBLIOGRAFIE}

ANONIEM. 1988. These statistics tell a story. Kindersorg/Child Welfare:1-9. Augustus/September. ASSER, C. 1984. Personen en Familierecht. Zwolle : Tjeenk Willink.

CLARK, A. HALL, M. \& MORRISON, L. 1972. The law relating to children and young persons. London : Buttcrworths.

DOOY EWEERD, H. 1933. Grondproblemen in de leer der Rechtspersoonlikheid. Deel II.

DOOYEWEERD, H. 1962. Verkenningen in de Wijsbegeerte, de Sociologie en de Rechtsgeschiedenis. Amsterdam : Buijten \& Schipperheijn.

DOOYEWEERD, H. 1931. De Wijsbegeerte der Wetsidee. Vol. II en III. Amsterdam : H.J. Paris.

FREEMAN, R. 1983. Law and the status of the child. New York : Oceana Publications Inc.

HANSARD

kyk

SUID-AFRIKA (Republiek). Volksraad.

HEATON, J. 1987. Die tugbevoegdheid ten opsigte van kinders. THRHR:398-404.

HERMAN, M. \& THEART, C. 1988. Kindermishandeling. Die maatskaplikewerk navorser/praktisyn, :1-7, Jun.

KAKEBEEKE VAN DER PUT, M.A. 1978. Compendium van het personen en familierecht. Deventer : Kluwer.

LUIJTEN, E.A.A. 1970. Het personen- en familierecht. Zwolle : Tjeenk Willink.

MNOOKIN, R.H. 1978. Child, family and the State. Boston and Toronto : Little, Brown \& Co.

OLMESDAHL, M.C. 1978. Paternal power and child abuse: An historical and cultural study in family violence. Toronto : Butterworths.

PAPPAS, M.A. 1983. Law and the status of the child. New York : United Nations Institute for Training and Rescarch.

PINCHBECK, I. \& HEWITT, I.I. 1973. Children in English society. London : Routledge \& Paul.

RYAN, P.A. \& GRANFIELD, D.D. 1963. Domestic relations - civil and common Law. Brooklyn : The Foundation Press Inc.

SNYMAN, C.R. 1983. Strafreg. Durban : Butterworths.

SOLER et al. 1983. Law and the status of the child. New York: Oceana Publications, Inc.

SPIRO, E. 1985. Law of parent and child. Kaapstad : Juta.

STRAUSS, D.F.M. 1978. Inleiding tot die Kosmologie. Bloemfontein : Saccum

SUID-AFRIKA (Rcpubliek). 1983. Debalte. Prctoria; Kaapstad : Staatsdrukker.

VAN DER VYVER, J.D. \& JOUBERT, D. 1985. Persone- en Familiereg. Kaapstad : Juta.

VAN OOSTEN, F. 1986. Kindermishandeling in die Suid-Afrikaanse reg met spesifieke verwysing na die Wet op Kindersory 74 van 1983. Social Work - Maatskaplike Werk: 86-93.

VAN WARMELO, P. 1971. Inleiding tot die Romeinse Reg. Kaapstad : Balkema.

VAN ZYL, F.J. \& VAN DER VYVER, J.D. 1982 . Inleiding tot die Regswetenskap. Durban : Butterworths. 
WETTE

Burgerlijk Wetboek (Nederland) Art 245

Capacity and Guardianship Law (Israel) 1962

Wet op Kindersong (Suid Afrika) 74 van 1983

\section{HOFSAKE}

Ex parte Minister of Justice: In re Rv Bolon 1941 AD 345

Hawthorne v Hawthorne 19503 SA 299 (C)

Meyer $v$ Van Niekerk 19761 SA 252 T

$R v$ Janke \& Janke 1913 TPA 382

Sv Fouche 19741 SA 98 (A)

Sv Maritz 19741 SA 266 (NK) 
